\title{
Produção de Imagens, Subjetivação e Trabalho Penitenciário: \\ Uma Contribuição às Clínicas do Trabalho
}

Techno-Poetic Analithic Devices of Activity a Contribution to the Clinic of Work

Producción de Imágenes, Subjetivación y Trabajo Penitenciario: Una Contribución a las Clínicas del Trabajo

Fernanda

Spanier Amador

Universidade Federal do Rio Grande do Sul

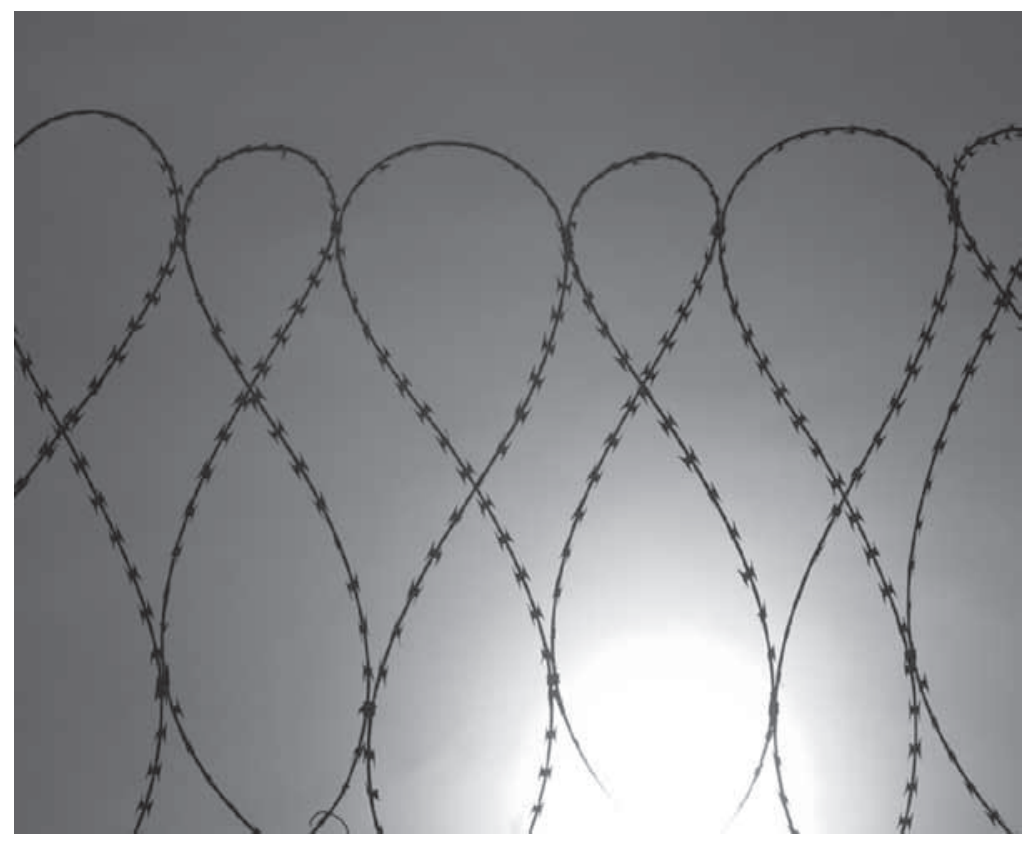


Resumo: Este artigo aborda aspectos desenvolvidos em nossa tese de doutorado. Seus temas centrais são imagem e subjetivação, que se desdobram em outros três, de forma transversa: trabalho, que ganha a cena como atividade, clínica, considerada por entre as formulações da clínica da atividade e dos procedimentos de crítica e clínica, e tecnologias digitais de imagem, em seus potenciais de estetização de si mesmo e do trabalho. Situada em uma casa destinada a mulheres que cumprem pena em regime semiaberto, a pesquisa teve como objetivo geral a criação de um campo de experimentação da atividade prisional pelo emprego de recursos tecnológicos de videografia digital junto a trabalhadoras agentes do sistema penitenciário. Exploramos as peculiaridades da atividade de produção de imagens sobre o trabalho prisional, o que caracteriza uma vertente metodológica em nosso percurso de pesquisa. Dedicamo-nos, ainda, a uma vertente teórica pela qual operamos um tensionamento conceitual visando a abrir veredas no que se refere à construção de possibilidades para uma clínica do trabalho valendo-nos das ferramentas analíticas da Filosofia da Diferença, da Ergologia e da Clínica da Atividade, enlaçando, assim, os planos dos fazeres profissionais, das tramas institucionais e da subjetivação.

Palavras-chave: Trabalho. Clínica. Imagem. Subjetivação. Trabalho feminino.

\begin{abstract}
This text concerns aspects developed in our doctoral thesis. Its central themes are image and subjectivation, which will result in another three subjects, such as: work, which implies, in this thesis, an activity; clinic, which involves the formulations of the clinic of activity and the critic and clinical procedures; and last but not least, digital technologies of image, in its potentials of aesthetization of the self and work. Situated in a feminine house shelter destined to women who fulfill penalty in half-open regimen, the research had as general objective the creation of a field of experimentation of prison activity through the implementation of technological resources of digital videography used by the workers of the penitentiary system. A few peculiarities from the activity of the production of images concerning the prison work were explored, what defines a methodological source in the history of this writing. To operate a conceptual tension that would open ways for the construction of possibilities for a clinic of work it was necessary to establish a few theoretical sources, such as the analytical tools from the Philosophy of difference, from ergology and from the clinic of activity, that emphasizes the affirmation of that differs in the plan of thinking and in the course of the work activities. The use of theoretical sources has also the aim of bringing together the plans of the professional attribute, the institutional schemes and the subjectivation.
\end{abstract}

Keywords: Work. Clinique. Image. Subjectivation. Working women.

Resumen: Este artículo aborda aspectos desarrollados en nuestra tesis de doctorado. Sus temas centrales son imagen y subjetivación, los cuales se desdoblan en otros tres, de forma transversal: trabajo, que sale a escena en tanto actividad, clínica, pensada por entre las formulaciones de la Clínica de la Actividad (Clot, 2006; 2008) y de los procedimientos de Crítica y Clínica (Deleuze, 1997) y tecnologías digitales de imagen, en sus potenciales de estetización de sí y del trabajo. Situada en una Casa destinada a mujeres que cumplen pena en régimen semi-abierto, la pesquisa tuvo como objetivo general la creación de un campo de experimentación de la actividad de prisiones por el empleo de recursos tecnológicos de videografía digital junto a trabajadoras agentes del sistema penitenciario. Exploramos las peculiaridades de la actividad de producción de imágenes sobre el trabajo carcelario, lo que caracteriza una vertiente metodológica en nuestro recorrido de pesquisa. Nos dedicamos asimismo, a una vertiente teórica, por la cual operamos un tensionamiento conceptual visando abrir veredas en lo que se refiere a la construcción de posibilidades para una Clínica del Trabajo valiéndonos de las herramientas analíticas de la Filosofía de la Diferencia, de la Ergología y de la Clínica de la Actividad, enlazando así, los planes de los quehaceres profesionales, de las tramas institucionales y de la subjetivación.

Palabras clave: Trabajo. Clínica. Imagen. Subjetivación. Trabajo de mujeres.

O que podem as imagens na intervenção em clínicas do trabalho ${ }^{1}$ ? Quais as peculiaridades, do ponto de vista do processo de sua experimentação, entre trabalhadoras do sistema prisional?

Essas foram as indagações iniciais que nos levaram a pesquisar a intrincada articulação entre os temas imagem, subjetivação, trabalho penitenciário, clínica e tecnologia digital de imagem. Do trabalho penitenciário, recolhemos sua dimensão institucional como produtor de modos de existência abordando-o, ao mesmo tempo, como atividade que diz respeito a investimentos vitais no curso do trabalho, capazes de abrir 
sendas em suas linhas de institucionalização. Já a abordagem clínica que sustentamos transita por entre a proposta da Clínica da Atividade $^{2}$ (Clot, 2006) e as ferramentas analíticas da Filosofia da Diferença (Deleuze, 2006). Apostamos, assim, em uma concepção de crítica e clínica (Deleuze, 1997) para fecundar a concepção de clínica sustentada por Clot (2008), que a define como prática voltada para a expansão do poder de agir acionado pelo afrontamento com os dilemas do trabalho e cujo traçado se faz pelos deslocamentos na ação individual e coletiva realizada. Assim o fazemos porque Deleuze (2006) se refere, a partir do pensamento de Espinosa, tal como o faz Clot (2008) no âmbito da clínica da atividade, a uma elevação do agir à sua mais alta potência, ou seja, à sua mais alta possibilidade de variar, de garantir sua existência por essa via. Tomamos, assim, o empreendimento clínico como afirmação do que está em vias de diferir, como ativação de possibilidades de vida no trabalho, como dispositivo para operações de criação frente aos poderes subjetivantes que o atravessam.

Dentre as tecnologias digitais de imagem, interessamo-nos, especialmente, pela videografia e por softwares de edição de imagem, pensando em acionar, pelo meio digital, um funcionamento simultâneo à formação de modos de sentir, de pensar e de agir e visando a percorrer as trilhas desse acoplamento - pelo qual se constituem espaços de agenciamentos, de pautas interativas e de relações de constitutividade, definindo-se e redefinindo-se, ao mesmo tempo, as possibilidades cognitivas individuais, socioinstitucionais e técnicoculturais (Maraschin \& Axt, 2005) - no que se refere aos processos de trabalho e de estetização da existência. Visamos, assim, a uma estética relativa à sensibilidade e ao sensível ao suscitar novas formas de subjetivação abertas ao cuidado de si e do outro (Foucault, 2006).
Para tanto, entregamos às agentes penitenciárias que atuam em uma casa albergue feminina (CAF) - que abriga mulheres em cumprimento de pena no regime semiaberto - câmeras de vídeo para produção de imagens, além de computadores para sua visualização, análise e manipulação como meios para criar espaços de experimentação em uma superfície de contato e de transdução, isto é, de deslocamentos, de transpasse, de recombinação entre o espaço característico dos equipamentos tecnológicos de imagem e o da experiência humana no trabalho. $\mathrm{O}$ propósito consistiu, assim, na criação de um ambiente aberto à imersão e à ficcionalização, visando à produção do que chamamos dispositivo tecno-poético de análise da atividade.

\section{Das prisões}

Interessou-nos explorar as prisões para além de sua materialidade concreta assumida em espaços geográficos de detenção. Pensando na direção das reflexões foucaultianas que as prisões estão estabelecidas nos mais ínfimos espaços da vida cotidiana pelas práticas disciplinares, perseguimos, também e especialmente, uma exploração da ideia de que as prisões de toda ordem vêm acompanhadas de políticas imagéticas que as mantém e sustentam.

Políticas que, como potencial e/ou prática relativa à dimensão da existência coletiva se fazem por determinados modos de olhar, modos que, por entre o aprisionamento e o desaprisionamento imagético, - por entre modos de olhar que engancham clichês nas imagens que tendem à reprodução de sentidos e aqueles que lançam o olhar ao campo de forças da imagem, o qual pode abrir seus sentidos -, fazem andar cursos institucionais e existenciais. Trata-se de políticas do olhar que, como práticas, remetem ao aparelho 
visual, porém ultrapassando-o e, por vezes, dele prescindindo por implicar o corpo inteiro como terminal por onde passam e se agenciam pensamentos, gestos, falas e ações, um corpo que, pelo pensamento de José Gil (2006), não é algo de que se tenha consciência, e sim, algo que pode impregnála por texturas finas que a obscurecem por tratar-se de canal de recepção das forças do mundo. Corpo e pensamento coexistem, co-habitam, na medida em que ele, o corpo, pode ser via para o movimento de forças e de pequenas percepções.

Tais políticas imagéticas, incidindo diretamente sobre os modos de viver com os outros e consigo mesmo, tanto apostam em linhas de individualidade egóica e personalizada por meio do que chamamos imagens-discurso quanto em linhas de vida singular em uma zona protoexistencial, por entre imagens-vibrato. Esta última, uma zona que remete ao impessoal e que é apresentada por Shérer (2000), a partir do pensamento de Deleuze (2006), como "lugar de criação, do universo da linguagem em todas as suas potências, liberado de sua dependência em relação ao sujeito pessoal que é enunciado com ele e, mais do que isso, por ele é penetrado, atravessado" (p.27).

Tratou-se, na pesquisa, de transitar por entre as prisões locais e as não localizáveis, por entre o que se dá a ver das prisões e o que delas se invisibiliza visibilizando, por entre campos fixos da delimitação de contornos que unificam totalizando-identitarizando e fluxos móveis de trajeto entre as coisas e as representações que temos delas, esses, fluxos passíveis de dissonância e de disjunção capazes de produzir diferença, isto é, de impulsionar as forças que dão existência às coisas, forças que, libertas das tramas da representação, escapam das normas da identidade e da semelhança (Deleuze, 2006).
Trata-se de diferença que converge para os princípios da singularidade, da ruptura e da descontinuidade, a qual perturba o pensamento tomado como ato recognitivo.

\section{O cárcere e suas technés: trabalho penitenciário feminino entre dramas e devires}

Na exigência de manter outras mulheres encarceradas, a tarefa das agentes penitenciárias é flagrantemente paradoxal: ver por um ajuste de suas lentes e ações com vistas à ressocialização de mulheres infratoras ou criminosas, ao reajustamento entre o visível e o enunciável fazendo ver nessas mesmas bases estando imersas em um contexto de verem-se e de fazerem ver-se por esses mesmos processos. Carceragem dupla se exerce, portanto.

Ao atuarem diretamente na gestão e no controle da multiplicidade humana, parecem fazê-lo pelo estabelecimento de suas próprias fronteiras identitárias. A serviço do biopoder, exercem sua função revestindo-se de camadas de assujeitamento em uma articulação de saberes e de poderes que tendem à homogeneização das singularidades, ao mesmo tempo em que se empenham em um esforço inglório para se distinguir em relação àquelas que detêm. Eis aqui o caminho de análise sugerido por Foucault (2010): ver a loucura pela sanidade e vice-versa. Do mesmo modo, parece-nos interessante ver o detento e aquele que encarna o papel de detentor.

Considerando o trabalho dimensão operatória, metodológica e técnica que convoca subjetivamente seus executores na linha da recognição e também esfera processual e inesgotavelmente variável que exige criação e invenção, podemos entendê-lo como esfera da vida humana 
ligada a um com(texto) mas também a um sem(texto), a uma dimensão que diz respeito ao domínio técnico e ao conhecimento científico e a outra que a eles resiste, a uma zona de distância em que as forças gravitam constituindo e (des)constituindo, ao mesmo tempo, saberes, fazeres e subjetividades. A partir de então, pensamos que trabalhar na prisão como funcionárias do sistema prisional posiciona as agentes penitenciárias em um compromisso com a manutenção de uma mecânica do poder, levando-as a tornaremse sua engrenagem como agentes do sistema e, ao mesmo tempo, envolvendo-as em uma zona de aberturas problemáticas por esse fazer.

Esse é o lastro no qual se desenrola a atividade de mulheres agentes penitenciárias, atividade que assume um sentido peculiar no pensamento de Schwartz (2000) ao dizer respeito a uma concepção mais geral da atividade humana de renormalização parcial dos meios de vida; trata-se de um movimento permanente no âmbito dos saberes produzidos no trabalho, ligado aos planos da técnica e da linguagem, produzindo normas antecedentes que são sempre renormalizadas no recomeço indefinido das atividades. Esse movimento, geralmente, evidencia uma distância abismal dos programas formais de preparo para o trabalho, uma vez que emergem das convocações diárias impostas pela lacuna entre Trabalho Prescrito e Trabalho Real. Tais conceitos originados da ergonomia designam, o primeiro, a esfera dos modos operatórios estabelecidos, baseados em uma esfera de conhecimentos formalizados, e o segundo, aquele que resiste à técnica por estar ligado ao fracasso das prescrições, convocando a produção de novos saberes derivados da experiência vivida.

Assim, entre a prescrição e o real, abre-se uma (des)formação que emerge das práticas e das experiências, implicando "dramáticas de usos de si" como diz Schwartz (2000, p. 44), isto é, envolvendo a produção de saberes engajados na história concreta do trabalho, dos encontros entre homens e mulheres e o meio de trabalho técnico e organizacional, os quais pressupõem uma singularidade.

Trabalhar, então, é gerir (Schwartz, 2004), é fazer algo sempre que nos deparamos com variabilidade e imprevisibilidade, é agenciar elementos não estereotipados e padronizados em um processo em que os trabalhadores recriam a si mesmos, no curso da atividade, permanentemente, na relação com os modos operatórios e com os instrumentos de trabalho. Gestão do trabalho e gestão de si operam, então, imbricadamente na atividade, e, estando sempre presentes como possibilidade no trabalho, colocam em cena os percursos da inventividade humana em relação a modos operatórios determinados, podendo, também, viabilizar inventividade no plano das formas de individualização que amarram as trabalhadoras penitenciárias aqui em questão em jogos de verdade.

A partir das definições de Trabalho Prescrito e Trabalho Real, empregamos a expressão Trabalho Virtual (Amador, 2009) para designar a esfera do Trabalho Real ligada ao campo de problematizações que aguardam atualização pela diferença, já que o sentido da palavra real não designa a realidade como estado de coisas, e sim, o revés, que se liga ao trabalho da invenção. Nesse sentido, Lévy (1996) contribui com suas formulações a respeito do virtual partindo da etimologia latina virtualis, derivada de virtus, que designa força, potência. Segundo ele, o virtual não se opõe ao real, mas ao atual; ele é uma espécie de complexo problemático, o nó de tendências ou de forças que acompanha uma situação, um acontecimento, um objeto ou uma entidade qualquer que chama um processo de resolução pela atualização. 
Encontramos em autores ligados à ergonomia francesa, à Clínica da Atividade e à Ergologia, respectivamente (Teiger, 1998; Clot, 2006; Schwartz, 2000), elementos para prosseguir nesse curso indagativo. Os autores, desenvolvendo conceitos como Trabalho Teórico, esse operado em uma zona irredutível ao Trabalho Prescrito e ao Trabalho Real, ligado às representações sociais, e Real do Trabalho como zona que transborda a atividade realizada remetendo ao inacabamento tanto teórico quanto operacional e subjetivo nas situações de exercício do trabalho e dramáticas do uso de si, em uma alusão à ideia de que a vida é sempre tentativa de criação, ainda que parcial, colocam-nos a perseguir uma definição de Trabalho Virtual, aquele que encontra lugar no entre do Trabalho Prescrito e do Trabalho Real e que, passando pelos dramas vividos pelos trabalhadores, atinge os devires do trabalho.

\section{Imagem e subjetivação}

Abordamos a imagem a partir de dois veículos: o corpo e o tecnológico. O primeiro tomamos como sistema de expressão alicerçado na percepção, na sensibilidade e no afeto, enquanto o segundo - materializado nos dispositivos de câmeras e computadores - consideramos, igualmente, sistema de expressão midiático e tecnológico. Referimonos ao termo sistema de expressão segundo as formulações de Guattari e Rolnik, (1986) a respeito das máquinas de expressão de natureza infrapessoais, relativas aos sistemas de percepção, de sensibilidade e de afeto, entre outros, e as de natureza extrapessoal, tais como a mídia e as tecnologias.

Quanto à subjetivação, nossa argumentação se sustenta em uma concepção que recusa a ideia de uma interioridade privativa. Assim, situamo-nos em uma zona processual dos modos de subjetivação na qual maneiras de pensar, de sentir e de agir são produzidas por um jogo de forças, de virtuais em curso de atualização (Deleuze \& Parnet, 1998). É de uma ontologia em ruptura que falamos, de um Ser que está no devir, e não o contrário, de que nos ocupamos, buscando elementos para considerarmos tal processualidade pelo complexo embaralhado de linhas, às quais podem as forças tomar como travessia, tanto em percursos de adesão ao poder quanto de criação face a ele.

Entre políticas imagéticas que apostam em imagens-discurso e políticas que investem em imagens-vibrato, é o corpo que é sempre investido como veículo, tanto para uma quanto para a outra. Entendemos o corpo como instância não intencional (Gil, 2006), como plano de afectos e perpectos anteriores a qualquer forma-sentimento ou formapercepção ligadas a contornos imagéticos, o qual acaba por constituir sua passagem.

Trata-se de corpo que, considerado em relação à imagem, invade a cena, invade a imagem em lugar de apenas ser seu receptáculo e guardião, corpo que, invadindo a consciência que podemos ter das imagens, pode fazê-las devir(ar), corpo que, como objeto primeiro de todo conhecimento e de toda visibilidade, tem as imagens como coisas a tocar, a acariciar, como sugere DidiHuberman (1998).

Pelos percursos da imagem que tem o corpo e as tecnologias digitais como veículo, percorremos, na pesquisa, sendas indagativas a respeito da experimentação imagética como dispositivo de subjetivação, no sentido de uma clínica feita pelo curso da atividade de produção de imagens acerca da atividade penitenciária.

Exploramos os equipamentos digitais e computacionais em seu potencial plástico e 
estético, o qual, em última instância, sustenta nossa concepção de potencial clínico das tecnologias digitais de imagem em uma interlocução com a Clínica da Atividade. Assim o fazemos para desenvolver uma linha argumentativa no sentido da afirmação das peculiaridades dos recursos digitais de imagem no que tange aos processos de subjetivação e a seus desdobramentos sociais e cognitivos.

Nessa direção, abrimos uma linha indagativa no que se refere à imagem digital que possibilita superar seus instrumentalismos manipulatórios, afirmando, em lugar disso, seu valor ontológico como princípio gerador de um novo real pela presentificação imagética (Parente, 1993) atentando, contudo, para o alerta do autor quando ressalta o fato de que as mutações e as rupturas tecnológicas que caracterizam a era digital devem ser avaliadas em função de duas tendências: a tendência à homogeneização universalizante (territorialização) e a tendência à heterogeneização singularizante (desterritorialização) da subjetividade.

A dimensão clínica da imagem que adotamos passa, dessa forma, pela experimentação de um olhar que está em uma espécie de perpétuo movimento, de busca aberta aos encontros, de aventura perceptiva por um plano de vibrações que gere possibilidades para que a vida em toda sua potência de variação se torne o centro para operações de criação e de escape aos poderes subjetivantes que a atravessam.

Para tanto, valemo-nos da contribuição de Deleuze $(1985,1990)$ ao pensar sobre o mundo acentrado que nos é dado ver e sobre a percepção que dele podemos obter pela imagem-movimento, um mundo que, para ele, é de universal variação, onde não existe direita, nem esquerda, nem centro; é um mundo no qual imagem é movimento, no qual cada imagem age sobre outras e reage a outras, é o mundo das imagens-movimento. Pela percepção, capturamos uma de suas faces entre todas as que compõem o universo das imagens-movimento.

Assim, percebemos e, por enquadramento, estabelecemos um sistema ótico que reenvia a um ponto de vista sobre o conjunto das partes. Porém, resta ainda um horschamp determinado pelo próprio campo estabelecido, e esse hors-champ possui dois aspectos que diferem em natureza: um aspecto relativo, pelo qual um sistema fechado reenvia, no espaço, a um conjunto que não se vê e que pode ser visto, deixando suscitar um novo conjunto visto ao infinito e um aspecto absoluto pelo qual o sistema fechado se abre a uma duração imanente ao todo do universo, que não é mais um conjunto e não é da ordem do visível. Desse modo, existem sempre dois aspectos do fora de campo: a relação atualizável com outros conjuntos, a relação virtual com o todo (Zabunyan, 2006).

Com respeito à narração, esta, para Deleuze $(1985,1990)$, a partir de seus estudos sobre cinema, não é mais que uma consequência de imagens aparentes nelas mesmas e de suas combinações diretas; ela jamais é um dado. A narração é uma consequência de imagens sensíveis nelas mesmas, ou seja, ela engaja signos pré-linguísticos (Zanbuyan, 2006), mas de cuja língua e enunciados linguageiros vão depender. Tal dimensão tornou-se central em nossa pesquisa, já que nos interessou explorar o potencial clínico das imagens em suas imbricações com o plano verbal em clínicas do trabalho.

\section{Por uma tecno-poética, uma poética da atividade}

Em nosso trabalho de pesquisa, centramonos na abertura de novas possibilidades 
conceituais e metodológicas para o campo das clínicas do trabalho. Do ponto de vista metodológico, discutimos o emprego da imagem videográfica como dispositivo clínico a partir do método da autoconfrontação, empregado em Clínica da Atividade, colocando relevo na imagem como plano específico de análise, diferente do plano conversacional, que é central nessa metodologia que acaba por se valer da imagem apenas como disparador do diálogo.

Considerando-se que em Clínica da Atividade (Clot, 2006; 2008) o que está em foco é o desenvolvimento do sujeito por meio de uma espécie de (des)vencilhamento dos modos de trabalho estabelecidos mediante uma expansão do poder de agir, do ponto de vista metodológico, há um momento decisivo: a singularidade, para ser objeto de estudo, deve integrar a compreensão de uma situação à unidade subjetiva e a uma experiência, e não somente às representações funcionais que a experiência supõe. Dito de outro modo deve procurar acompanhar os escapes em relação aos modos operacionais de referência em que, na atividade, trabalhadores e trabalhadoras se envolvem.

Situando-se no que define como ambiente habitual, a Clínica da Atividade propõe a análise da atividade de trabalho pela autoconfrontação a partir da instauração de um espaço de co-análise -entre pesquisador e trabalhadores -, mediante o emprego de imagens videografadas dos trabalhadores e trabalhadoras em situação. Trata-se de acompanhar aquilo que eles e elas fazem com as provações pelas quais passam e com as soluções que encontram, ou não encontram, a fim de enfrentá-las (Clot, 2006).
O objeto da análise refere-se, então, às condições de vida habitual apresentadas em imagem pelas pessoas em situação de trabalho, de modo a levá-las a se interrogarem sobre o que se veem fazendo, buscando acompanhar as trilhas de uma psicologia prática, relativa aos objetivos e às motivações dos atos humanos para renormalizar o trabalho diante dos desafios do meio. Desse modo, a autoconfrontação diz respeito a uma zona relativa ao pensamento em ato de homens e mulheres no trabalho, a um pensamento que, ligado aos deslocamentos provocados pela atividade, se opera nas passagens, nos trânsitos, nos pontos transversos, os quais, pensamos, forçam o pensamento a outrar-se.

O emprego de câmeras de vídeo na autoconfrontação serve para recriar artificialmente a vivência das experiências no trabalho e o pensamento que a acompanha. Desse modo, Clot (2006) diz interessar-se pela busca de uma metodologia nem estritamente compreensiva, nem limitadamente explicativa: nem explicação externa dada pelo pesquisador, alerta ele, nem simples descrição do vivido pelo sujeito. Parecenos, então, que sua proposta é a de uma metodologia implicativa, por isso entendendo um caminho que acompanha a promoção do pensamento no curso da atividade, tanto por parte do pesquisador quanto por parte dos trabalhadores e trabalhadoras da atividade em questão.

Referimos ao termo implicativo a partir do conceito de implicação, que, como legado de René Lourau, apresenta-se próximo dos conceitos de transdução e de transversalidade, permitindo levar em conta os elementos e os acontecimentos que se propagam na singularidade de uma situação, seja de pesquisa, seja de intervenção, seja em situações cotidianas. Apresentando proximidade com o conceito de problematologia, de Meyer, apud 
Lourau (2004b), a implicação refere-se a um processo de desarranjo pelo qual se formulam perguntas, problemas, incessantemente (Lourau, 2004a, 2004b).

Assim, uma metodologia implicativa, tal como parece ser a proposta pela Clínica da Atividade, consiste no acompanhamento do percurso, no qual a atividade e aquele que trabalha se transformam ao mesmo tempo, tal como se dá no processo das dramáticas dos usos de si mencionadas por Schwartz (2004) e levadas em consideração por Clot (2006, 2008) em suas análises.

Para Clot (2006), o registro meticuloso da gravação de sons e imagens dos arquivos de linguagem e técnicas da atividade real mostrou-se uma opção metodológica bastante produtiva por oferecer, aos olhos dos trabalhadores e trabalhadoras, um registro sistemático dos meios desviados, graças aos quais aqueles que trabalham se desincumbem das provações que a situação Ihes impõe, atestando que o real da atividade ultrapassa não somente a tarefa prescrita, mas também a própria atividade realizada.

Contudo, mesmo empregando a imagem videográfica, o autor enfatiza a análise no plano da verbalização a partir das imagens, tomando-as como meio para o diálogo. Parece-nos, entretanto, que há pelas imagens gravadas uma espécie de materialização das dissonâncias que, na atividade, fazem tocar seus virtuais, acionando, assim, um processo de rastreamento dos desvios cuja materialidade imagética auxilia a percorrer, pondo em foco um plano de análise imagético peculiar que não parece ser tematizado na metodologia da autoconfrontação. Tratase de um plano de signos não linguísticos que reclama uma lógica da sensação não discursiva em vez de uma lógica da significação (Sauvagnargues, 2005), plano que implica uma síntese perceptiva imediata, que implica, também, uma experiência da duração concreta que lhe é correlativa.

A imagem videográfica figura, em nosso ponto de vista, como esfera acentrada que nos é dada ver, uma esfera de variação que, pela percepção, começa a ser rastreada guardando uma relação com toda uma esfera visível, mas também não visível na e pela imagem: com um plano de relação atualizável e outro virtual.

Faita (2007) salienta, em texto dedicado à imagem animada como artefato no quadro metodológico de uma clínica da atividade, que, por haver uma dimensão não diretamente acessível na análise da atividade - aquela relativa ao real do trabalho -, é preciso criar condições para colocar em obra dispositivos técnicos que permitam aos sujeitos transformarem sua experiência vivida em objeto de uma nova experiência. Trata-se, segundo ele, de abrir uma via para o redoublement ${ }^{3}$ da experiência vivida cujo suporte em vídeo é uma das possibilidades. Assim, o autor destaca que o recurso da imagem consiste em uma possibilidade de oferecer ao olhar de trabalhadores e trabalhadoras seu trabalho à sua frente em uma espécie de duplicação da situação de trabalho, constituindo a imagem objeto de ação. Configurando, pela imagem, uma via para uma nova atividade, pela qual os trabalhadores e trabalhadoras buscam, pelos meios de produção, um "meio para si" (Clot, 2006, p.132), a imagem em Clínica da Atividade operaria como porta de acesso aos conflitos da atividade.

Mas é no trabalho de Meritan (2008) que encontramos elementos mais contundentes para prosseguir em nossas indagações acerca da peculiaridade do dispositivo de imagem para uma clínica pela atividade. Para ela, é 
de fundamental importância pensar sobre "o que é ver", já que existem, em seu ponto de vista, dois planos distintos, porém interrelacionados, de análise: um não linguageiro e outro linguageiro, esse relativo à atividade conversacional travada a partir das imagens.

Criticando uma posição de que a imagem produzida para autoconfrontação consiste em um traço da atividade real, Meritan menciona que ver e falar são meios diferentes empregados nesse dispositivo, chamando a atenção para o fato de que os trabalhadores não fazem apenas algo do que dizem a partir das imagens, mas também do que veem, sendo o que dizem relativo, também, ao que veem. Dito de outro modo, a atividade de ver mediatiza e/ou agencia a atividade de falar, de modo que os fatos do trabalho em imagens não são apenas pretexto ao comentário ou explicação dirigidos ao outro, mas ganham sentidos insuspeitos na experiência de ver.

A partir da ideia de duplicação da imagem sugerida por Faita (2007), remetemo-nos à imagem como simulacro em Deleuze (1985, 1990, 1992), imagem dessemelhança que nada tem a ver com cópia por ser, justamente, rebelde ao modelo, imagem que deixa de ser segunda em relação ao modelo. Figurando como dimensão co-extensiva à matéria fluente ou à sua variação, simulacro como imagem, imagem como simulacro constitui e reconstitui sempre o começo do mundo como princípio de individuação. Essa imagem, assim, se refere a um tempo ontológico, àquele relativo a uma dimensão protossubjetiva anterior a qualquer ser, anterior a qualquer fechamento, porque referida às forças que Ihes dão existência e que, assim entendida, pode ajudar-nos a utilizar como tema o emprego da imagem em Clínica da Atividade como via para o Trabalho Virtual. De Meritan (2008), por sua vez, dirigimo-nos a pensar nas especificidades da imagem como dispositivo cuja peculiaridade em seus efeitos de linguagem também remetem a essa dimensão.

Assim, seguindo o rastro de tais indagações, agregamos ainda outras questões, agora relativas ao modo de produção das imagens. Considerando que as imagens dos trabalhadores em situação de trabalho são, na autoconfrontação, definidas pelo grupo participante da pesquisa mas realizadas pelo pesquisador para posteriormente retornar ao grupo que as assiste e discute, perguntamonos: como o fato de produzir as imagens de seu trabalho e, mais tarde, editá-las, como fizemos em nossa pesquisa, opera em termos metodológicos? Perguntamo-nos ainda, a respeito da peculiaridade da experiência que propusemos, que esta não consistiu em produzir imagens de agentes penitenciárias em situação de trabalho a serem posteriormente analisadas pelo plano conversacional, e sim, de se colocarem em atividade de produção de cenas relativas ao trabalho prisional. Temos, assim, a cena, e não a palavra, como mote do dispositivo clínico.

Com base nessas indagações, propusemos às agentes penitenciárias que participaram da pesquisa um modo específico de análise da atividade, agregando à linguagem verbal sobre tais imagens como meio de verbalizar a ação - tal como proposto na autoconfrontação - a produção de imagens videografadas, digitalizadas e abertas à imersão pelas próprias agentes penitenciárias. Tratou-se de pôr em cena uma espécie de pensar e de dizer por imagens.

Tivemos como problema central a seguinte indagação: qual a potência clínica - no sentido do favorecimento de uma elaboração estilístico-estetizante de si e do gênero da atividade (Clot, 2006) - que apresenta 
a produção de imagens realizada pelas próprias agentes do sistema penitenciário acerca do trabalho prisional? Para investigar tal problemática, entregamos a câmera de vídeo em suas mãos durante uma semana para que produzissem cenas de seu trabalho na prisão, cenas que foram posteriormente assistidas com a pesquisadora e entre elas, bem como editadas com o emprego de software de edição.

Pela autoconfrontação se estabelece "um ciclo entre aquilo que os trabalhadores fazem, aquilo que eles dizem daquilo que fazem e, por fim, aquilo que eles fazem daquilo que dizem" (Clot, 2006, p.136), conforme já mencionamos. Em nossa proposta, em sintonia com a busca do autor, propusemos uma experimentação que agrega um sutil diferencial que se localiza, fundamentalmente, naquilo que as agentes penitenciárias fazem, no que mostram/imagetizam do que fazem, no que experimentam pelo que mostramimagetizam na esfera videográfica e nos vídeos digitalizados e no que fazem do que mostram/imagetizam.

Visando a colocar-nos no coração da experimentação imagética, nosso objetivo consistiu em explorá-la como dispositivo para a criação na atividade, presente na proposta da Clínica da Atividade (Clot, 2006), isso porque o autor salienta que a finalidade da análise não é remediar erros ou reproduzir a experiência, e sim, deixar nascer a ação, darIhe passagem pelo curso da vida que verte no trabalho. Longe de ater-se aos procedimentos operatórios, são as sendas da criação de si e de modos de trabalhar que o autor percorre, colocando em cena um nível de formação no trabalho operado no momento mesmo de trabalhar.
Nossas indagações metodológicas percorreram possibilidades oferecidas pela imagem digital para uma clínica do trabalho, especialmente por duas dimensões: uma relativa à experimentação das possibilidades de simulação como um acesso privilegiado aos virtuais do trabalho que, como criação de mundos e de si, se alcem, posteriormente e nesse processo, ao plano do Trabalho Real, e outra, referente ao debate de uma experimentação por parte das agentes penitenciárias como videastas que, ao produzirem cenas e as editarem - com os recursos de digitalização da imagem -, possam estabelecer pontes entre elas, a ficionalização e o Trabalho Real, criando um território de plasticidade tanto de si mesmas quanto de seu trabalho.

De acordo com a metodologia da autoconfrontação, porém por meio de um dispositivo que chamamos de tecno-poético de análise da atividade, dadas suas variações em relação à autoconfrontação, ressalta-se que a atividade real consiste no foco da análise, tratando-se de fazer à atividade dos sujeitos novas perguntas que eles mesmos não se fariam, disparando um processo indagativo acerca da atividade pelo meio associado à pesquisa, para fazer aflorar a variabilidade do processo de trabalho.

\section{Agentes penitenciárias devir(ando) videastas: (olhares) em experimentação}

Pela experimentação da produção de imagens, evidenciamos que, durante todo o processo, o que pautou a produção das cenas, primeiro com a câmera, depois na edição, foi a oportunidade de dar vazão a algo das dramáticas dos usos de si em situação de trabalho. Assim, delas, por elas, com elas e contra elas as agentes tiveram a oportunidade de colocar sua atividade em movimento, 
diferentemente, em um caminho pelo qual a experimentação imagética pareceu potente para introduzir uma variação da atividade ordinária, abrindo novas possibilidades de ação para expandir o poder de agir sobre o mundo e sobre si mesmas.

Visando a apresentar rotinas de trabalho, durante o percurso, tais rotinas aparecem acompanhadas dos dramas enfrentados pelas agentes penitenciárias na situação de trabalho ordinária, dramas que são revividos pela experimentação por imagens, que introduz linhas problemáticas em relação ao Trabalho Real pela especificidade dos signos envolvidos.

Por dois momentos diferentes - o da produção das cenas com a câmera e o da edição -, operar com imagens consistiu em deslizar por uma esfera de experiência (relativa à atividade penitenciária), por uma experiência videográfica que, tendo como produto uma matéria (filmada e editada), excede e, ao mesmo tempo, reduz o real que se (re)apresenta imageticamente. Produzir cenas com a câmera de vídeo consistiu, assim, em um momento no qual se captou o imediato, o instantâneo, o que dura na ação, enquanto na edição desse imediato se passou a tentativas de relações entre as imagens na vivência de uma espécie de montagem. Produzir cenas do próprio trabalho consistiu, ainda, em uma tarefa pela qual de dentro, quer dizer, não como estrangeiras à sua própria atividade, se buscou uma certa estrangeiridade pelo deslocamento nos modos de olhar para o trabalho, de ver outramente, de outros pontos de vista, da câmera que está a serviço da vigilância, uma câmera a serviço do encontro com elementos que forçam a pensar, que lançam a uma dissolução de formas, a uma dissolução de pontos de vista, a deslizamentos de sentidos pela expressão impregnada no modo de ver.
Produzir as imagens como não estrangeiras ao próprio trabalho implica reconhecer que tal produção parte do gênero da atividade, como em vários momentos pudemos evidenciar ao longo da pesquisa, gênero que marca o olhar da agente como videasta mas que, contudo, joga com uma espécie de espontaneidade das imagens como sugere Tarkovski (1998), para quem a essência do trabalho de um cineasta é esculpir o tempo. Assim, ser cineasta é ser, em certa dimensão, estrangeiro a e pela própria obra.

Entre produzir imagens a partir de uma intenção inicial, que, no caso da pesquisa em questão se apresentou como um esforço de mostrar suas rotinas de trabalho e os modos como se sentem nessas situações, por um vivido sobre o qual deslizou a imagem, emerge na experimentação a vivência por um deslize imagético que convoca os afectos, marcando um trabalho poético instaurado a partir da própria atividade penitenciária mostrada.

Consideramos essa poética como nuances que podem levar a uma estilização, pela imagem, do próprio gênero da atividade penitenciária, uma vez que, para Bergson (1999), o plano afectivo guarda uma relação de decorrência quanto à percepção, possuindo, ainda, uma diferença de natureza referente a ela, uma vez que os processos perceptivos se aplicam à extensão das coisas, enquanto os afectivos se creem como inextensivos. Diz ele que a afecção "não se limita a refletir a ação de fora; ele luta, e absorve assim algo dessa ação. Aí estaria a origem da afecção. Poderíamos, portanto, dizer, por metáfora, que, se a percepção mede o poder refletor do corpo, a afecção mede seu poder absorvente" (p.58). Do olho que visou mostrar rotinas de trabalho ao olho que nada almejou e que por isso mesmo se surpreendeu diante de determinados elementos que se deram à 
visão, esse foi o movimento que marcou o percurso das agentes em experimentação imagética, enlaçando, nesse processo, as dramáticas dos usos de si experimentadas na situação da atividade penitenciária e as linhas de debate que, por tais dramáticas, ganharam corpo pela experimentação com os signos da imagem.

Do olho que buscou a cena à cena que buscou o olho. Operando por escolhas de imagens a produzir, porém empunhando uma câmera que não filma o que o olho decide ver, a produção de cenas pelas agentes foi marcada por deslizamentos, tanto durante o momento mesmo de fazer as imagens quanto de assisti-las e editá-las.

Mais do que nos ocuparmos das soluções criadas pelas agentes diante dos conflitos de sua atividade, interessou-nos acompanhar o traçado de seus problemas formulados durante a experimentação do dispositivo de pesquisa, com o incentivo a que elas próprias colocassem suas questões atentando para as indagações que emergiram da conversa entre elas e entre elas e a pesquisadora, mobilizadas pela atividade de produção de imagens sobre seu trabalho na prisão. Tratou-se, assim, de um empreendimento eminentemente cartográfico (Amador \& Fonseca, 2009), em que nos concentramos dispersamente no traçado das problemáticas criadas pelas trabalhadoras penitenciárias nessa experimentação.

Passando pelo gênero da atividade, foi nas estilizações que procuramos pousar nossa atenção nas (trans)bordas da atividade. Por isso, nossa condução como pesquisadora se deu no sentido de formular questões de modo a manter vivo o curso de problematizações das mulheres participantes da pesquisa, de modo a atingir o real da atividade (Clot, 2007) ou, como dizemos no âmbito de nossa pesquisa, o Trabalho Virtual.
Por trilharmos um caminho metodológico em aproximações com a Clínica da Atividade, ressaltamos seu caráter de ação para agir sobre o trabalho e transformá-lo, subvertendo, portanto, a máxima de conhecer para transformar. Assim, nosso percurso consistiu em provocar a mudança mediante um campo de experimentação para, então, analisar. Enfocando o aprender na ação e não o saber que dela deriva, é de uma atividade em devir pela produção de imagens sobre o trabalho e sobre a própria atividade penitenciária que nos ocupamos.

Desse modo, a dimensão clínica no âmbito de uma clínica pela atividade, tal como experimentamos, referiu-se à perturbação do plano discursivo que suporta o gênero da atividade penitenciária, pela própria característica da matéria signalética da imagem animada. Pensamos que essa distância pode ser aberta para a colocação de problemas, para o fluxo do pensamento em relação à atividade real e para o real da atividade, distância que, por sua vez, reivindica espaço em uma esfera discursiva no plano da linguagem verbal.

Portanto, o esforço como pesquisadora foi o de fomentar uma conversa com e entre as trabalhadoras em questão. Tratou-se de andar na direção apontada por Clot (2007): construir um instrumento de análise coletiva para compartilhar a incompreensão ligada ao real da atividade, ao Trabalho Virtual, a ser convertido em material de análise. Buscou-se, assim, o estranho como objeto do pensamento. Porém, mesmo passando pelo vivido do trabalho, foi pelo plano de sensações, de perceptos e de afectos que a ele se liga, foi pelo diálogo e pela experimentação imagética que nos interessamos sobremaneira.

Além de incursionar por uma memória empírica, aquela que se refere ao déjà vu 
do trabalho, procuramos as linhas de um esquecimento essencial, aquele que força o pensamento a apreender o impensado, o que não pertence à ordem do inteligível e sim, à do sensível, conduzindo, por um jamais vu, a uma espécie de futuro anterior do trabalho.

Assim, o que se ofereceu para análise em nossa pesquisa consistiu, justamente, na atividade de produção de vídeos a respeito do trabalho ordinário na prisão, criando, por sua vez, uma dimensão extraordinária que passou a ser mote para a abertura de dissonâncias entre trabalho ordináriotrabalho extraordinário.

Pensamos que a dimensão que ganhou corpo para análise foi, justamente, o plano de uma acontecimentalização do trabalho por imagens em que não foi a palavra e sim, a cena, que movimentou uma conversa das agentes penitenciárias consigo mesmas e entre si, a partir da abertura de linhas problemáticas acerca do trabalho na prisão. Por entre a imagem de certo modo aprisionada em seus limites de materialidade tecnológica e a imagem liberta que vaga pelo ilimitado do pensamento em uma processualidade corporal, traçou-se, então, uma dinâmica na qual se inscreveram, pela atividade de produção de imagens sobre o trabalho, novas possibilidades para a atividade penitenciária viabilizadas pelo acesso imagético às suas virtualidades.

Entendendo que a imagem gera a palavra e não apenas a suporta, que, do prélinguístico das imagens produzidas do trabalho penitenciário se produz um discurso sobre a atividade prisional, foi então, desse percurso que nos ocupamos na pesquisa em que a imagem foi considerada um meio de elevar o olhar para além do empírico, fazendo nascer o visionário, tornando visíveis as forças que, na e pela imagem, não são visíveis por si mesmas. Tratou-se de incursionar por um dispositivo para ver outramente, apostando em uma espécie de expansão do poder de agir no trabalho por experimentações que apostam na expansão do poder de ver. 
Fernanda Spanier Amador

Psicóloga, Mestre em Psicologia Social (PUCRS), Doutora em Informática na Educação (UFRGS) pesquisando Interfaces Digitais em Educação, Arte, Linguagem e Cognição com Doutorado Sanduíche (CAPES) no CNAM/Paris junto ao Laboratório de Psicologia do Trabalho coordenado por Yves Clot. Pós-doutoranda em Educação/UFRGS (CNPQ). Professora adjunta da Universidade Federal do Rio Grande do Sul, Rio Grande do Sul, RS - Brasil.

E-mail: feamador@uol.com.br

Endereço para envio de correspondência:

Rua Silva Jardim, 475/604. Mont1Serrat, Porto Alegre - RS - Brasil CEP: 90450-071

Recebido 10/11/2009, 1ㄹ Reformulação 18/1/2011, Aprovado 31/3/2011 


\section{Referências}

Amador, F. S. (2009). Entre prisões da imagem, imagens da prisão. Um dispositivo tecno-poético para uma clínica do trabalho. Tese de doutorado. Programa de Pós-Graduação em Informática na Educação, Universidade Federal do Rio Grande do Sul, Porto Alegre, RS.

Amador, F. S., \& Fonseca, T. M. G. (2009). Da intuição como método filosófico à cartografia como método de pesquisa. Arquivos Brasileiros de Psicologia, 61(1), 30-37.

Bergson, H. (1999). Matéria e memória (2a ed., P. Neves, Trad.). São Paulo: Martins Fontes.

Blackburn, S. (1997). Dicionário Oxford de Filosofia. Rio de Janeiro: Jorge Zahar.

Clot, Y. (2006). A função psicológica do trabalho. Petrópolis, RJ: Vozes.

Clot, Y. (2007). A clínica da atividade: uma metodologia de intervenção no trabalho como atividade coletiva e dialógica. Trabalho apresentado na Universidade Federal Fluminense. Rio de Janeiro, RJ.

Clot, Y. (2008). Travail et pouvoir d'agir. Paris: Presses Universitaires de France.

Deleuze, G. (1985). A imagem-movimento. Cinema 1. São Paulo: Brasiliense.

Deleuze, G. (1990). A imagem-tempo. Cinema 2. São Paulo: Brasiliense.

Deleuze, G. (1992). Conversações. São Paulo: Editora 34.

Deleuze, G. (1997). Crítica e clínica. São Paulo: Editora 34.

Deleuze, G. (2006). Diferença e repetição. Rio de Janeiro: Graal.

Deleuze, G., \& Parnet, C. (1998). Diálogos. São Paulo: Escuta.

Deleuze, G., \& Guattari, F. (1980). Mille plateaux. Paris: Minuit.

Didi-Huberman, G. (1998). O que vemos, o que nos olha. São Paulo: Editora 34.

Faita, D. (2007). L'image animée comme artefact dans le cadre méthodologique d'une analyse clinique de l'activité. @ ctivites, 4(2), 3-15. Recuperado em 19 de abril de 2011 de http://www.activites.org/v4n2/v4n2.pdf

Foucault, M. (2006). A Hermenêutica do Sujeito. São Paulo: Martins Fontes.

Foucault, M. (2010). História da Loucura na Idade Clássica. São Paulo: Perspectiva, 2010.

Gil, J. (2006). Entrevista concedida a Suely Rolnik e publicada sob o título Abrir o Corpo publicada no Catálogo Ligia Clark: da obra ao acontecimento. Somos o molde. A você cabe o sopro.

Guattari, F. (2003). A paixão das máquinas. In Cadernos de Subjetividade. O Reencantamento do Concreto. Núcleo de Estudos da Subjetividade. Programa de Estudos PósGraduados em Psicologia Clínica da PUC-SP. São Paulo: HUCITEC/EDUC.

Guattari, F., \& Rolnik, S. (1996). Micropolítica - cartografias do desejo. Petrópolis, RJ: Vozes.

Lévy, P. (1996). O que é o virtual? Rio de Janeiro: Editora 34

Lhuilier, D. (2006). Cliniques du travail. Paris: Éditions Érès.

Lourau, R. (2004a). Implicação-transdução. In S. Altoé (Org.), René Lourau: analista institucional em tempo integral. São Paulo: HUCITEC.

Lourau, R. (2004b). Implicação: um novo paradigma? In S. Altoé (Org.), René Lourau: analista institucional em tempo integral. São Paulo: HUCITEC.

Maraschin, C., \& Axt, M. (2005). Acoplamento tecnológico e cognição. In V. B de Oliveira, \& J. Vigneron (Org.), Sala de aula e tecnologias. São Bernardo do Campo, SP: UMESP.

Meritan, A. (2008). L'image animée en clinique de l'activité. Objet, instrument, discours. Memoire de master recherche. Paris: CNAM.

Parente, A. (Org.). (1993). Imagem-máquina. Rio de Janeiro: Editora 34

Sauvagnargues, A. (2005). Deleuze et l'art. Paris: Presses Universitaires de France.

Schérer, R. (2000). Homo tantum. O impessoal: uma política. In E. Alliez, Gilles Deleuze: uma vida filosófica. São Paulo: Editora 34.

Schwartz, Y. (2000, jul./dez.). A comunidade científica ampliada e o regime de produção de saberes. Trabalho \& Educação, 7, 38-46.

Tarkovsky, A. (1998). Esculpir o tempo. São Paulo: Martins Fontes.

Teiger, C. (1998). El trabajo, esse oscuro objeto de la ergonomia. In Ergonomia: conceptos y métodos (pp 141-162). Madri: Editoria Computense.

Zabunyan, D. (2006). Gilles Deleuze. Voir, parler, penser au risque du cinéma. Paris: Presses Sorbonne Nouvelle. 